\title{
Determination of Piles Bearing Capacity using Empirical Methods and (AllPile 6) Software -Cases studies Portsudan and Khartoum Cities
}

\author{
Abusamra A. A. Yousif ${ }^{1}$ and Elkhomuini H. M. Ali $^{2}$ \\ ${ }^{1}$ Dept. of Civil Engineering and Faculty of Engineering, Albaha University, Aqiq, Kingdom Saudi Arabia; ${ }^{2}$ Dept. of Civil \\ Engineering and Faculty of Engineering Sciences, Omdurman Islamic University, Omdurman, Sudan. \\ *Correspondence: Abusamra32@ hotmail.com (Abusamra A. A. Yousif, Assistant Professor, Dept. of Civil Engineering and \\ Faculty of Engineering, Albaha University, Aqiq, Kingdom Saudi Arabia).
}

\section{ABSTRACT}

Different methods have been used to determine the pile bearing capacity such as static equations, dynamic equations, empirical methods (EMs), numerical methods, computer software programs, and the pile static load test, these methods were giving different values for pile bearing capacity. In this paper, three empirical methods (Ems) have been selected (Brinch-Hansen, Chin-Kondner, and Decourt) and (AllPile 6) software (AP) has been applied to determine the capacity load of piles for six cases study of drilled concrete piles with a diameter ranging from $800 \mathrm{~mm}$ to $1500 \mathrm{~mm}$ and embedded length ranged $10.5 \mathrm{~m}$ to $26 \mathrm{~m}$. Four of those six piles are located at Portsudan city near the red seacoast and two piles are located in Khartoum city. The results of the pile bearing capacity (PC) calculations obtained using the abovementioned different methods were compared with results produced by the pile load test. In all six cases study, the settlement of piles was limited, settlement failure was not reached. The results show that the AllPile 6 (AP) and the three mentioned empirical methods (Ems) gave reasonable piles bearing capacity, the (AP) and (BHM) gave the better result than the CKM and DM. While (DM) gave results similar to results determined using the (CKM). However, it was not preferred to use the (CKM) and (DM), unless the failure settlement has occurred in the pile load test.

Keywords: Pile bearing capacity, Empirical method, Brinch method, Chin-Kondner, and Decourt method.

\section{INTRODUCTION:}

Many studies and researches were conducted on the comparison of different methods for determining piles bearing capacity such as the following. E. Gehan showed a comparison between various prediction methods to obtain the ultimate bearing capacity of the pile, this study compared the measured result of ultimate pile load capacity for forty-four piles with results obtained using four empirical methods (Brinch-Hansen,1963; Chin-Kondner, 1970), Modified (Chin, 1980; Decourt, (1999) and two semi-empirical methods (using correlation with in situ results of UniversePG I www.universepg.com
SPT and CPT), these data of soil collected from different Egyptian soils. The study noted that all empirical methods applied gave suitable results, but there are variations in the results with respect to the different methods. In addition, the study concluded that (BHM) and (DM) gave satisfactory results of ultimate load capacity of piles (Abdelrahman et al., 2003). Eslami et al. (2014) provided a study for determining piles axial capacity based on in-situ tests and static analysis. The results obtained by these methods were more accurate pile s load capacity (Eslami et al., 2014). 
Lastiasih et al. introduced some methods for evaluating load capacity based on the pile load test. 15 out of 130 pile loading tests reach failure conditions and the remaining cases without reaching failure. In this study, different methods are used to determine pile loading capacity. It was concluded that all methods gave more suitable results and it was recommended to use the method which gives the lower bearing (Lastiasih et al., 2014; Lastiasih and Sari 2020).

Samuel et al. (1999) proposed a method for determining the ultimate bearing capacity of piles from non-failed load tests. Different empirical methods also were used such as Davisson's criterion method, Shape of the Curve method, Limited total settlement method, De Beer's log-log method, BHM and Chin's method. The proposed method and empirical methods were calculated and compared with the measured results of pile load tests (Paikowsky \&Tolosko, 1999). In this study, full-scale static and dynamic tests of reinforced concrete cast-in-placepiles were proposed for determining the pile loading capacity. The results obtained were more suitable (Kostov \& Dikov, 2015). Nonlinear analysis was carried out for deep foundations subjected to lateral loads to estimate pile loading capacity. The values of deflections and bending moments were agreed with field tests (Evans et al., 1994). The prediction of the PC is more useful in foundation design. This study was aimed to propose a soft computing technique to estimate the pile bearing capacity using the Gaussian process regression (Dowlatshahi et al., 2020). Another study was conducted depending on a cone penetration test and piezocone penetration test for evaluating direct axial loading capacity. It was concluded that all tested piles have failed at the end of the static (Hasanzadeh et al., 2013). This study was aimed to apply an artificial neural network model improved with genetic algorithm optimization technique to forecast piles loading capacity (Nazir et al., 2014). In this study, different machine learning algorithms including decision tree and perceptron artificial neural network are used to model the pile bearing capacity of cohesion-less soil (Zhou et al., 2020). Another study is conducted to predict single pile loading capacity using in-situ test and prediction methods such as hyperbola, exponent curve, log curve, and gray theory. It is concluded that exponential and hyperbola methods are better than the other method (Iqbal et al., 2020; Zhang et al., 2006).

In this study, different direct and indirect methods such as static and dynamic approaches are used to estimate the loading capacity of driven piles if fie grained soil (Abasia et al., 2014). This work is aimed to determine the bearing capacity of single and pile groups in cohesion-less and cohesive soils (Coyle \& Sulaiman 1970). In this work, the discrete method is used to analyze the pile-soil interaction and loading transfer mechanism. Stress and strain distribution in pile-soil interaction in multi-layer soils by using the discrete method (Hong \& Mechanics 2002).

\section{Objectives}

The paper is aimed to:

1) Determine the pile bearing capacity (PC) by using empirical methods (EMs) and software program (AP).

2) Compare results obtained and to evaluate the variation in the results obtained from different methods and expect to what extend this variation can be effect calculating bearing capacity.

\section{METHODOLOGY:}

The research method is based on analysis and comparison of the results for the sample pile bearing capacity by applying the EM (Brinch-Hansen, 1963; Chin-Kondner, 1970; Decourt, 1999) and determining the bearing capacity of the same sample pile by using a software program (AP). In this paper, a concrete drilled shaft pile was used (Ali, 2018).

\section{Brinch-Hansen method (BHM)}

Brinch-Hansen (1963) developed a method which assumed that, the failure is achieved from the assumption that hyperbolic relationships exist between the load and settlement. Brinch-Hansen assumption that the shape curve of pile load-settlement is like that, when the settlement (S) are plotted against the square root of settlement divided by the corresponding load $S / Q$, the crossing points of and $(S / Q)$ plot in straight line having a slope $\left(C_{1}\right)$ and a Y-intercept $\left(C_{2}\right)$ as shown in Fig 1. Two methods are suggested $(80 \%$ and $90 \%$ criteria), the first method if the load of $80 \%$ $\mathrm{Qu}$ corresponded the settlement $25 \% \mathrm{Su}$ and the second method if the load of $90 \% \mathrm{Qu}$ corresponded the settlement $50 \% \mathrm{Su}$, then the pile load capacity 
(failure) $\mathrm{Qu}$ and the settlement at failure $\mathrm{Su}$ are determined from following equations:

$$
\begin{aligned}
& \mathrm{Qu}=1 / \sqrt{\left(C_{1} C_{2}\right)} \\
& \mathrm{Su}=C_{2} / C_{1}
\end{aligned}
$$

Brinch-Hansen considered that the load - settlement curve as shown in Fig $\mathbf{2}$ is parabolic curve which can determine by using following equation:

$$
\mathrm{Q}=S /\left(C_{1} \mathrm{~S}+C_{2}\right)
$$

Fellenius, (2001) recommended the $80 \%$ criterion Brinch-Hansen, which generally gives a good result to the actual pile load capacity, gained from the static test results.

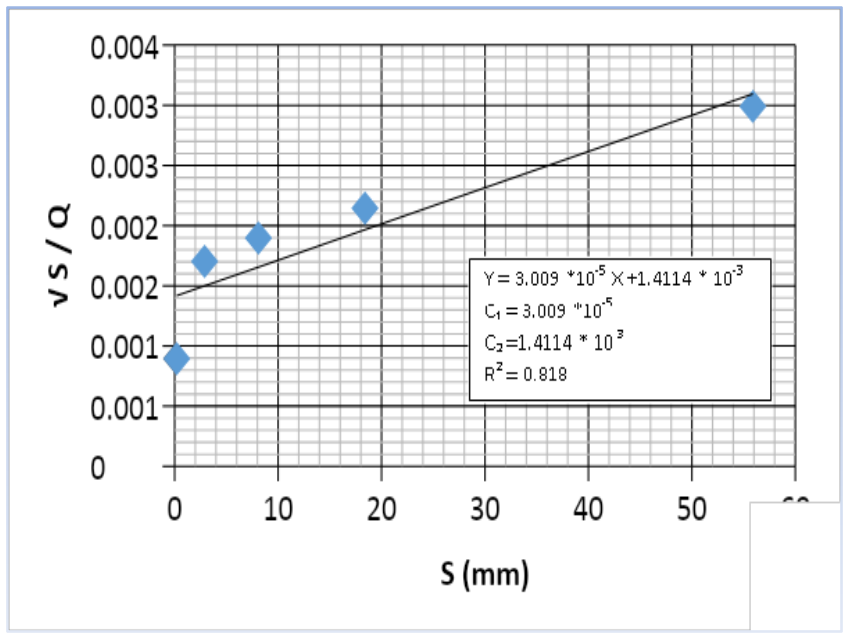

Fig 1: Linear regression for BHM.

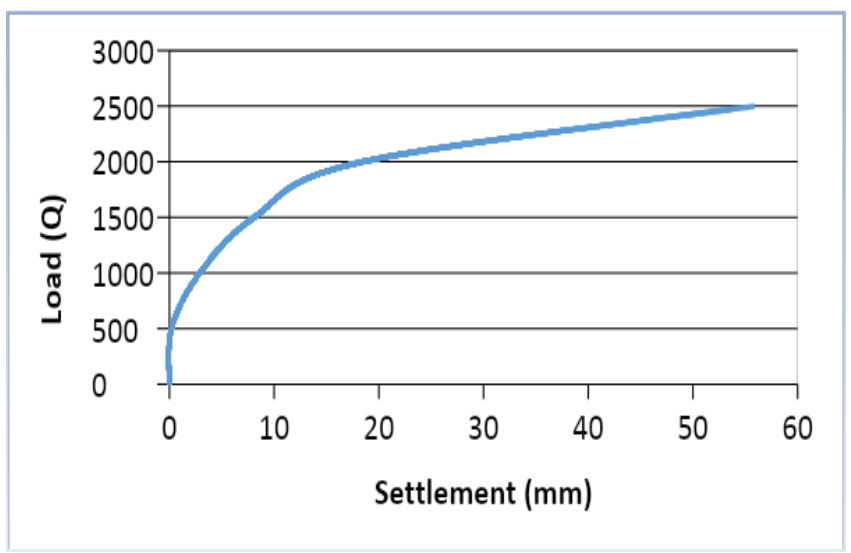

Fig 2: Load - settlement curve (parabolic curve), using BHM.

\section{Chin-Kondner method (CKM)}

Chin's method, (1970) developed method to piles of the general work by Kondner, (1963), the method was assumed that the hyperbolic relationships exists between the load and settlement as shown in Fig 5. CKM assumption that the shape curve of pile load settlement UniversePG I www.universepg.com is like that, when the settlement $(\mathbf{S})$ are plotted against the settlement divided by corresponding load (S/Q), the crossing points of $(\mathbf{S})$ and $(\mathrm{S} / \mathrm{Q})$ plot in straight line having a slope $\left(C_{1}\right)$ and a Y-intercept $\left(C_{2}\right)$ as shown in Fig 3. The pile load capacity (failure) $(\mathrm{Qu})$ corresponding to settlement at failure $(\mathrm{Su})$, then the $(\mathrm{Qu})$ and $(\mathrm{Su})$ are determined from following equation:

$\mathrm{Qu}=\sqrt{1 / C 1}$

The parabolic curve mentioned above can be determined by using equation:

$\left.\mathrm{Q}=\mathrm{S} / \sqrt{ } C_{1} \mathrm{~S}+C_{2}\right)$

Where: $C_{1}$ is the slope of the straight line;

$C_{2}$ is the $\mathrm{Y}$-intercept of the straight line.

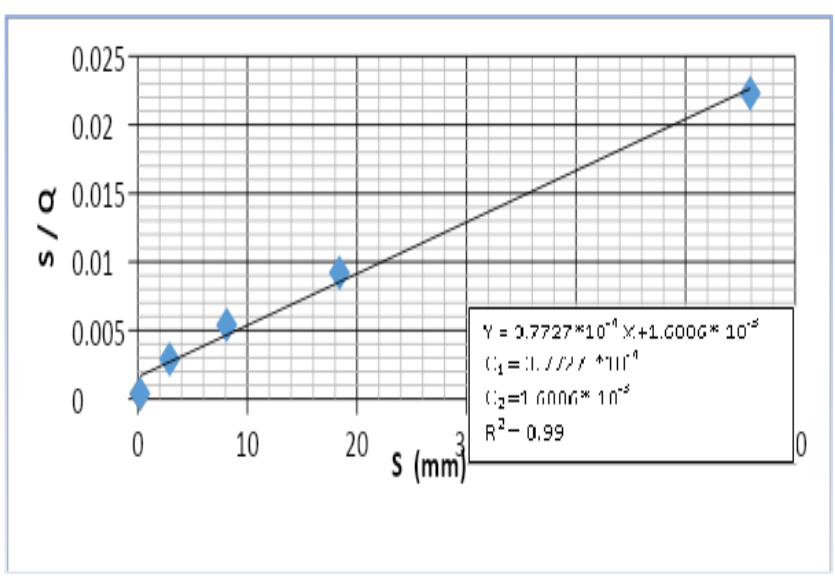

Fig 3: Linear regression for CKM.

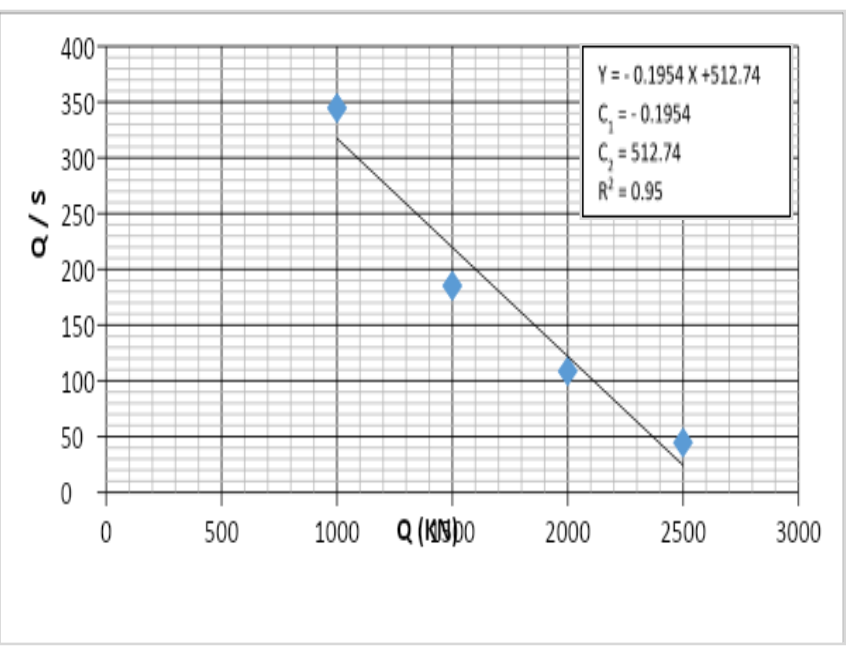

Fig 4: Linear regression for DM. 


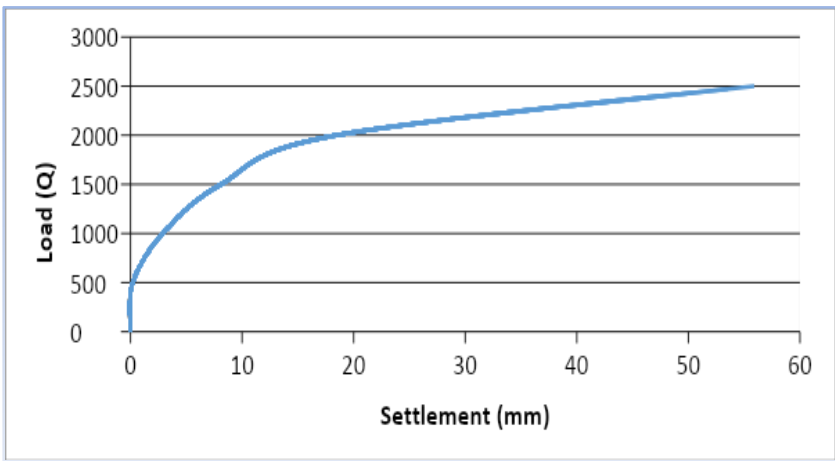

Fig 5: Load - settlement curve (parabolic curve) using CKM.

\section{Decourt method (DM)}

In 1999 Decourt developed method which assumed that, the method was assumed that the hyperbolic relationships exist between the load and settlement as shown in Fig 6. Decourt assumption that the shape curve of pile load - settlement is like that, when the load (Q) are plotted against the load divided by corresponding settlement $(\mathrm{Q} / \mathrm{S})$, the crossing points of $(\mathrm{Q})$ and $(\mathrm{Q} / \mathrm{S})$ plot in straight line having a slope $\left(C_{1}\right)$ and Y-intercept $\left(C_{2}\right)$ as shown in Fig 4. The pile load capacity (failure) $(\mathrm{Qu})$ corresponding to settlement at failure $(\mathrm{Su})$, then the $(\mathrm{Qu})$ and $(\mathrm{Su})$ are determined from following equation:

$$
\mathrm{Qu}=C_{2} / C_{1}
$$

The parabolic curve mentioned above can be determined by using equation:

$\mathrm{Q}=C_{2} S /\left(1-C_{1} \mathrm{~S}\right)$

Where: $C_{1}$ is the slope of the straight line; $C_{2}$ is the Yintercept of the straight line; $\mathrm{Qu}$ is pile load capacity (failure); $\mathrm{Su}$ is pile settlement at failure; $\mathrm{S}$ is pile settlement corresponding to $\mathrm{Q}$ and $\mathrm{Q}$ is the applied load

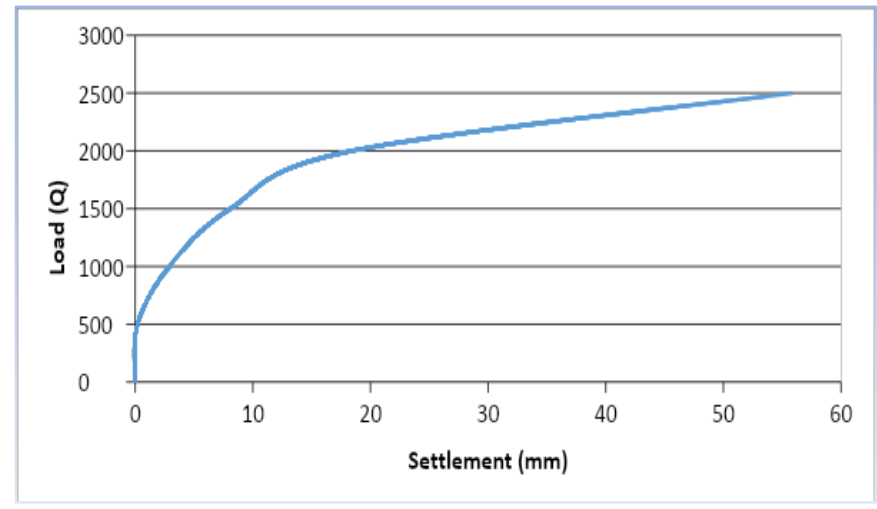

Fig 6: Load - settlement curve (parabolic curve), using DM.

\section{Cases Study}

In this section, the different six sites were taken to calculate the pile bearing capacity. It will be defined as the following.

\section{All Pile 6 Software (AP)}

AP is widely used by engineering companies, consultancies, and agencies in the United States and around the world. AP is a windows-based analysis program, which analyzes all types of piles and shallow foundations. The AP consists of six main windows for inputting data and two main windows for outputting results. The following steps describe using the AP software:

a. The first window (Pile Type) contains information about the pile type, the project title, and units (English or Metric).

b. The second window (Pile Profile) includes information about the Pile such as length (L), Top height $(\mathrm{H})$ above N.G.L, and surface angle (As), batter angle $(\mathrm{Ab})$.

c. The third window (Pile Properties) contains information about pile properties such as depth from pile top to beginning of each section, the pile shape and material, pile outside condition, pile inside material, pile diameter variation, $\%$ in-side material in total area (At), in addition to the calculator.

d. The fourth window (Load and Group) contains information about the number of piles (single pile,

(7) group piles, tower foundation), types of loading on the pile and \% load supported by pile cap.

e.The fifth window (Soil properties) comprised information about soil profile such as distance from the ground to beginning each layer, depth of groundwater, surface elevation (optional input), the soil type, and number of SPT.

f. The sixth window (Advanced page) contains information related to analysis as the zone of zero friction, zone of negative friction, analysis parameters, and settlement calculation method (Vesic method or Rees method).

g. By the end of step six, all input data will be completed and the program has ready to give output results. The program has the ability to give the results in two options Vertical analysis results or Lateral analysis results; also it can prepare summary reports. 


\section{Site (A)}

Portsudan housing towers project, tower No.8, site (A) is found in Portsudan city on the coast of the RedSea. One drilled concrete pile without a case is tested, with a diameter of $1000 \mathrm{~mm}$ and embedded length of $30 \mathrm{~m}$, the static load test was done by the ESD Company. The site (A) investigation and test results generally indicated a relatively deep top layer of alluvial deposits that are underlain by completely weathered limestone. Groundwater was measured at $0.68 \mathrm{~m}$ to $1.28 \mathrm{~m}$ depth below the ground surface. The SPT test results indicated very loose to very dense. The geotechnical report is established in laboratory and field tests made on five boreholes with deep of $40 \mathrm{~m}$ carried by an engineeering service and design (ESD) company, it is the famous consultancy companies in geotechnical engineeering in Sudan.

\section{Site (B)}

Portsudan towers project, tower No.7, site (B) is situated in Portsudan city on the coast of the Red Sea. Boarded concrete pile without a case has diameter of $100 \mathrm{~mm}$ and embedded length of $24 \mathrm{~m}$ is tested. The static load test was done by the ESD Company. The site (B) investigation and test results generally indicated a deep top layer of alluvial deposits that are underlain by completely weathered limestone. Groundwater at about one meter depth below ground surface. The SPT test results indicated very loose to very dense. The geotechnical report is constructed by laboratory and field tests made on five boreholes with deep of $30 \mathrm{~m}$, carried out by the engineering service and design (ESD) company.

\section{Site (C)}

Portsudan new depots (LPG), site (C) is positioned near Portsudan city on the coast of the Red Sea. Drilled concrete pile without a case has diameter 1500 $\mathrm{mm}$ and embedded length of 10.5 meters is tested, the load test was done by ESD Company. The site C investigation and test results generally indicated completely to moderately weathered coral reef limestone that contains marine shells and fossils. Groundwater at about three-meter depth below ground surface. The SPT test results indicated moderate to very dense. The geotechnical report is created by laboratory and field tests made on seven boreholes with deep of $15 \mathrm{~m}$ to $20 \mathrm{~m}$, carried out by an engineering UniversePG I www.universepg.com service and design (ESD) company.

\section{Site (D)}

Portsudan new power plant project, site (D) is located near Portsudan city on the coast of the Red Sea. Drilled concrete pile without a case has diameter 800 $\mathrm{mm}$ and embedded length of $16 \mathrm{~m}$ is tested, the load test was done by ESD Company. The site D investigation and test results generally indicated completely too moderately weathered coral reef limestone that contains marine shells and fossils. Groundwater at about three-meter depth below ground surface. The SPT test results indicated moderate to very dense. The geotechnical report is established by laboratory and field tests made on 20 boreholes with deep of $20 \mathrm{~m}$ to $30 \mathrm{~m}$, carried out by (ESD) company.

\section{Site (E), pile P-1 and pile P-2:}

Altadamon Islamic bank, a new tower (22 floors) located in Khartoum city Almogran. Two drilled concrete piles have a diameter of $1200 \mathrm{~mm}$ and embedment lengths of $25.5 \mathrm{~m}$ and $26 \mathrm{~m}$ were tested, the groundwater at about four-meter depth below ground surface. The surrounding soil contains alluvial clay, alluvial sand, silty sand, mudstone, and sandstone with quartz pebbles. The SPT test results indicated medium dense to very dense. The summary of cases studies was presented in Table 1.

\section{RESULTS:}

The results were obtained by application of (AP) and referring to soil data of selected sites and by application of EMs (Brinch-Hansen, Chin- Kondner and Decourt) which has been explained in section 3 were illustrated in Tables (2-8). In all cases, the applied settlement of the piles was restricted, settlement failure was not attained. The results were summarized as follows:

a) The average factor of safety of pile load cap-acity is 4.5 with a standard deviation is 2.56 , which appeared in Brinch- Hansen method as presented in Table 3.

b) The minimum value of factor of safety of pile load capacity is 1.4 which appeared in the (DM), as illustrated in Table 3.

The (AP) and (BHM) gave better results in comparison to the other two methods. Comparison of results between ultimate load capacity determined by (AP) 
and results obtained using EMs as shown in Table 4. Comparison of the results between pile load capacity at constant settlement obtained by using (AP) software and stated (EM) with results of pile load test was shown in Tables 7-8.

Table 1: Cases studies data summary.

\begin{tabular}{|c|c|c|c|c|c|c|}
\hline No & Case & Project name & Location & Diameter(mm) & EmbedmentDepth $(\mathbf{m})$ & Working Load (Ton) \\
\hline 1 & Site A & Tower No.8 & Portsudan & 1000 & 30 & 180 \\
\hline 2 & Site B & Tower No.7 & Portsudan & 1000 & 24 & 170 \\
\hline 3 & Site C & LPG depots & Portsudan & 1500 & 10.5 & 500 \\
\hline 4 & Site D & Power plant & Portsudan & 800 & 16 & 140 \\
\hline 5 & Site E,P-1 & Altadamon & Khartoum & 1200 & 26 & 600 \\
\cline { 5 - 7 } & Site E,P-2 & Islamic bank & Khartoum & 1200 & 25.5 & 550 \\
\hline
\end{tabular}

Table 2: Results of single pile bearing capacity (PC) using different Ems.

\begin{tabular}{|c|c|c|c|c|c|c|}
\hline No & Case & Design Load (Ton) & AP (Ton) & BHM(Ton) & CKM(Ton) & DM(Ton) \\
\hline 1 & Site A & 180 & 663 & 511 & 282 & 246 \\
\hline 2 & Site B & 170 & 685 & 462 & 269 & 235 \\
\hline 3 & Site C & 500 & 1729 & 3901 & 2144 & 2183 \\
\hline 4 & Site D & 140 & 736 & 1095 & 393 & 380 \\
\hline 5 & Site E,P-1 & 600 & 1495 & 1981 & 1094 & 1025 \\
\hline 6 & Site E,P-2 & 550 & 1378 & 1437 & 1385 & 1269 \\
\hline
\end{tabular}

Table 3: Safety Factor of single pile bearing capacity (PC) using different Ems.

\begin{tabular}{|r|c|c|c|c|c|}
\hline No & Case & AP & BHM & CKM & DM \\
\hline 1 & Site A & 3.7 & 2.8 & 1.5 & 1.4 \\
\hline 2 & Site B & 4 & 2.7 & 1.6 & 1.4 \\
\hline 3 & Site C & 3.45 & 7.8 & 4.3 & 4.7 \\
\hline 4 & Site D & 5.25 & 7.82 & 2.8 & 2.7 \\
\hline 5 & Site E,P-1 & 2.5 & 3.3 & 1.8 & 1.7 \\
\hline 6 & Site E,P-2 & 2.5 & 2.6 & 2.5 & 2.3 \\
\hline
\end{tabular}

Table 4: Comparison between ultimate (PC) obtained by (AP) and Ems.

\begin{tabular}{|c|c|c|c|c|}
\hline No & Case & AP/BHM & AP/CKM & AP/DM \\
\hline 1 & Site A & 1.3 & 2.4 & 2.7 \\
\hline 2 & Site B & 1.5 & 2.5 & 3 \\
\hline 3 & Site C & 0.4 & 0.8 & 0.8 \\
\hline 4 & Site D & 0.7 & 1.9 & 1.9 \\
\hline 5 & Site E,P-1 & 0.75 & 1.4 & 1.4 \\
\hline 6 & Site E,P-2 & 0.96 & 1 & 1.1 \\
\hline
\end{tabular}

Table 5: Piles load Capacity (PC) using (AP) and EMs at same measured settlement from the pile load test.

\begin{tabular}{|c|c|c|c|c|c|c|c|}
\hline No & Case & Measured Settlement(mm) & MeasuredLoad (Ton) & AP (Ton) & BHM (Ton) & CKM (Ton) & DM (Ton) \\
\hline 1 & Site A & 0.37 & 180 & 60 & 234 & 212 & 232 \\
\hline 2 & Site B & 0.26 & 170 & 24 & 210 & 204 & 206 \\
\hline 3 & Site C & 1.1 & 500 & 60 & 533 & 514 & 511 \\
\hline
\end{tabular}




\begin{tabular}{|c|c|c|c|c|c|c|c|}
\hline 4 & Site D & 0.16 & 140 & 18.5 & 139 & 134 & 137 \\
\hline 5 & SiteE,P-1 & 1.4 & 600 & 460 & 652 & 664 & 679 \\
\hline 6 & SiteE,P-2 & 1.5 & 550 & 278 & 566 & 600 & 606 \\
\hline
\end{tabular}

Table 6: Piles load Capacity (PC) using (AP) and EMs at same measured settlement from the pile load test.

\begin{tabular}{|c|c|c|c|c|c|c|c|}
\hline No & Case & Measured Settlement(mm) & MeasuredLoad (Ton) & AP (Ton) & BHM(Ton) & CKM(Ton) & DM(Ton) \\
\hline 1 & Site A & 1.46 & 270 & 135 & 248 & 260 & 242 \\
\hline 2 & Site B & 0.57 & 255 & 43 & 230 & 235 & 221 \\
\hline 3 & Site C & 1.8 & 750 & 97 & 691 & 729 & 728 \\
\hline 4 & Site D & 0.73 & 280 & 44 & 279 & 275 & 272 \\
\hline 5 & SiteE,P-1 & 3.34 & 900 & 725 & 854 & 855 & 840 \\
\hline 6 & SiteE,P-2 & 2.52 & 825 & 425 & 811 & 778 & 768 \\
\hline
\end{tabular}

Table 7: Comparison between piles load Capacity (PC) obtained by (AP) and EMs to measured load at same settlement.

\begin{tabular}{|c|c|c|c|c|c|c|c|}
\hline No & Case & $\begin{array}{c}\text { Measured } \\
\text { Settlement(mm) }\end{array}$ & $\begin{array}{c}\text { Measured } \\
\text { Load (Ton) }\end{array}$ & $\begin{array}{c}\text { AP/ } \\
\text { (measuredload) }\end{array}$ & $\begin{array}{c}\text { BHM/ } \\
\text { (measuredload) }\end{array}$ & $\begin{array}{c}\text { CKM / } \\
\text { (measuredload) }\end{array}$ & $\begin{array}{c}\text { DM / } \\
\text { (measuredload) }\end{array}$ \\
\hline 1 & Site A & 0.37 & 180 & 0.33 & 1.3 & 1.18 & 1.29 \\
\hline 2 & Site B & 0.26 & 170 & 0.14 & 1.23 & 1.2 & 1.21 \\
\hline 3 & Site C & 1.1 & 500 & 0.12 & 1.07 & 1.03 & 1.02 \\
\hline 4 & Site D & 0.16 & 140 & 0.13 & 0.99 & 0.96 & 0.98 \\
\hline $\mathbf{5}$ & Site E, P-1 & 1.4 & 600 & 0.77 & 1.09 & 1.10 & 1.13 \\
\hline $\mathbf{6}$ & Site E, P-2 & 1.5 & 550 & 0.50 & 1.03 & 1.1 & 1.10 \\
\hline
\end{tabular}

Table 8: Comparison between piles load capacity (PC) using (AP) and EMs at the same settlement.

\begin{tabular}{|c|c|c|c|c|c|c|c|}
\hline No & Case & $\begin{array}{c}\text { Measured } \\
\text { Settlement(mm) }\end{array}$ & $\begin{array}{c}\text { Measured } \\
\text { Load (Ton) }\end{array}$ & $\begin{array}{c}\text { AP/ } \\
\text { (Measuredload) }\end{array}$ & $\begin{array}{c}\text { BHM / } \\
\text { (Measuredload) }\end{array}$ & $\begin{array}{c}\text { CKM / } \\
\text { (Measuredload) }\end{array}$ & $\begin{array}{c}\text { DM/ } \\
\text { Measuredload) }\end{array}$ \\
\hline 1 & Site A & 1.46 & 270 & 0.50 & 0.92 & 0.96 & 0.90 \\
\hline 2 & Site B & 0.57 & 255 & 0.17 & 0.90 & 0.92 & 0.87 \\
\hline 3 & Site C & 1.8 & 750 & 0.13 & 0.92 & 0.97 & 0.97 \\
\hline 4 & Site D & 0.73 & 280 & 0.16 & 0.99 & 0.98 & 0.97 \\
\hline 5 & Site E,P-1 & 3.34 & 900 & 0.80 & 0.95 & 0.95 & 0.93 \\
\hline 6 & Site E,P-2 & 2.52 & 825 & 0.51 & 0.98 & 0.94 & 0.93 \\
\hline
\end{tabular}

\section{DISCUSSION:}

All the mentioned methods stated in the paper (AP and the mentioned EMs) determined the satisfactory PC, but there is variation in piles factor of safety. The discussion of results was summarized as follows:

1) It was noticed that, for the piles' load test, the settlement corresponding 1.5 working load is very small, (less than $3.5 \mathrm{~mm}$ ) as illustrated in Table 6, and the vertical load - settlement curves did not achieve failure settlement, for that it is much difficult to determine the actual PC.

2) In comparison with the small values of settlement UniversePG I www.universepg.com corresponding to the large values of loads, it was found that the AP and the BHM gave the bestpredicted PC results as shown in Table 2.

3) It is difficult to make comparisons of PC obtained using the EMs and AP program because the vertical load - settlement curves did not achieve failure settlement. For the previews reason, a method for the comparison is suggested to take constant settlement corresponding to the different PC obtained using each method as shown in Table 5-6.

4) In the suggested method, it was observed that 
BHM, CKM, and DM gave results slightly different from measured results at load test with a margin of about $12 \%, 9 \%$, and $11 \%$ respectively as shown in Table 7-8. The AP gave results totally different from obtained results from the load.

5) DM gave results of pile load capacity similar to those results determined using the CKM with the factor of safety about 2.5 for working load, it was found that both two methods underestimated results.

6) It was found that results obtained using AP underestimate the PC as illustrated in Table 5 - 6.

\section{CONCLUSION AND RECOMMENDATIONS:}

The conclusion was drawn as follows: In all samples of the study, the vertical load - settlement curves did not achieve failure settlement, so it is much difficult to know the true ultimate bearing capacity of piles. The BHM and AP gave the best results of the ultimate PC. Comparison of the results of pile bearing capacity using the different EM with that results obtained from load pile tests at constant settlement, it found that BHM, CKM, and DM gave results slightly different from results obtained by load test with a margin about $12 \%, 9 \%$, and $11 \%$ respectively, while the AP program gave results totally different from measured results of load test as shown in Table 7-8. The advantage of CKM and DM is that it was fast to draw the curve of vertical load-settlement during the pile load test in progress.

Recommendations were summarized as follows:

1) It was recommended to use (AP), to determine the $\mathrm{PC}$ for the reason that, it gave satisfactory results, in addition, that it gave simple and economical design.

2) In addition to using the computer software program, the BHM may use for quality control assurance depending on the size and condition of the project.

3) Further researches are required by using different empirical and computer software methods taken into consideration the whole variables affecting the pile load capacity such as soil types, pile dimensions, materials, and construction methods, a large number of samples should be considered in those researches.

UniversePG I www.universepg.com

\section{ACKNOWLEDGEMENT:}

We are so much acknowledged to Prof. Dr. Tayeb Hassan Onsa for his guidance to this research.

\section{CONFLICTS OF INTEREST:}

The authors declare that they have no competing interests with respect to the research.

\section{REFERENCES:}

1) Abdelrahman, G., E. Shaarawi and K. Abouzaid,-(2003). Interpretation of axial pile load test results for continuous flight auger piles. Proc. of the 9 Arab Structural Engineering Conf., Abu Dhabi, UAE. https://doi.org/10.4236/jsea.2013.69A004

2) Ali, E. H. M. O. M., (2018). Determination of Piles Bearing Capacity using Empirical Methods and Computer Software Program (AllPile 6), Sudan University of Science and Technology. http://repository.sustech.edu/handle/123456789/20 735A

3) Coyle, H. M. and I. H. J. H. R. R. Sulaiman, (1970). "Bearing capacity of foundation piles: state of the art." 333, 87.

4) Duncan, J. M., L. T. Evans Jr and P. S. J. J. o. g. e. Ooi, (1994). "Lateral load analysis of single piles and drilled shafts." 120(6), 10181033.

5) Eslami, A., I. Tajvidi and M. J. I. J. o. C. E. Karimpour-Fard, (2014). "Efficiency of methods for determining pile axial capacity-applied to 70 cases histories in Persian Gulf northern shore." 12(1), 45-54.

6) Hong-liang, D. J. R. and S. Mechanics, (2002). "Numerical solution of depth effect and determination method of bearing capacity for pile with expanded end." 23(1), 97-102. https://doi.org/10.1371/journal.pone.0248502

7) Iqbal MA, Mamun AMA, Hossain MR, and Hassan MK. (2020). The metric of space-time curvature in a weak gravitational field and it's consequence in Newtonian approximation, Int. J. Mat. Math. Sci., 2(5), 87-92. https://doi.org/10.34104/ijmms.020.087092

8) Kardani, N., A. Zhou, M. Nazem, S.-L. J. G. Shen and G. Engineering, (2020). "Estimation of bearing capacity of piles in cohesionless soil using optimised machine learning approaches." 
38(2), 2271-2291.

9) Kostov, V. and D. J. I. M. S. G. S. Dikov (2015). "Bearng Cpacity of Cast in Place Piles on The Basis of In-Situ Sttic Load Tests." 2, 111.

10) Lastiasih, Y. and P. Sari, (2020). Comparison of ultimate bearing capacity based on empirical method, interpretation of loading pile test and finite element. IOP Conference Series: Materials Science and Engineering, IOP Publishing. https://doi.org/10.1088/1757-899X/930/1/012036

11) Lastiasih, Y., I. D. J. J. o. E. Sidi and T. Sciences, (2014). "Reliability of Estimation Pile Load Capacity Methods." (1).

12) Momeni, E., M. B. Dowlatshahi, F. Omidinasab, H. Maizir, D. J. J. A. J. f. S., (2020). Armaghani and Engineering "Gaussian process regression technique to estimate the pile bearing cap-acity." 45(10), 8255-8267.

13) Momeni, E., R. Nazir, D. J. Armaghani and H. J. M. Maizir, (2014). "Prediction of pile bearing capacity using a hybrid genetic algorithm-based
ANN." 57, 122-131.

https://doi.org/10.1016/j.measurement.2014.08.00 $\underline{7}$

14) Paikowsky, S. and T. Tolosko, (1999). Extrapolation of pile capacity from non-failed load tests, Federal Highway Administration, Report No. FHWA-RD-99-170, Washington, DC.

15) Shooshpasha, I., A. Hasanzadeh and A. J. I. J. o. G. Taghavi, (2013). "Prediction of the axial bearing capacity of piles by SPT-based and numerical design methods." 4(2), 560-564. https://doi.org/10.3390/app10051871

16) Shooshpasha, I., H. Mola-Abasia and I. J. I. J. o. E. Amiri, (2014). "Evaluation of static and dynamic methods for determining the bearing capacity of the driven pipe piles." 27(2), 307-314. https://doi.org/10.5829/IDOSI.IJE.2014.27.02B.14

17) Zhang, W.-w., Z.-h. LU and C. J. J. o. G. U. o. T. Chen, (2006). "Determination of ultimate bearing capacity of individual piles [J]." 26(3), 370-373.

Citation: Yousif AAA., and Ali EHM. (2021). Determination of piles bearing capacity using empirical methods and (AllPile 6) software -cases studies Portsudan and Khartoum cities, Int. J. Mat. Math. Sci., 3(6), 113-121. https://doi.org/10.34104/ijmms.021.01130121@ @ @ 